\title{
Effects of Antimicrobial Agents Used for Therapy of CNS Infections on Dissociated Brain Cell Cultures
}

\author{
URS B. SCHAAD, KATHRIN GUENIN, CHRISTINE STEFFEN, AND NORBERT HERSCHKOWTIZ
}

Department of Pediatrics (Inselspital), University of Berne, CH-3010 Berne, Switzerland

\begin{abstract}
The prediction, measurement, and monitoring of neurologic toxicity of antibacterial agents is an exceedingly difficult matter. In this study we investigated if in vitro exposure of cultured brain cells to antibacterial drugs could predict neurotoxicity in man. Effects of antibiotics used for therapy of bacterial CNS infections on growth and differentiation in dissociated rat brain cell cultures were studied over 24 days in culture, the drugs being added from 10 to 17 days in culture, the main differentiation phase of rat CNS cells. Our results demonstrated a reversible inhibition of cerebral sulfate transferase activity $(p<0.001$ or $<0.01)$ and to a lesser extent $(p<0.001$ or NS) of DNA synthesis in brain cell cultures by the highest concentrations studied of amikacin, cefuroxime, and ceftazidime which correspond to peak cerebrospinal fluid values attained by intraventricular therapy in patients. Accumulation of DNA reflects brain cell growth whereas cerebral sulfate transferase activity parallels brain cell differentiation. Our findings indicate that intraventricular therapy could be more toxic with amikacin, cefuroxime, and ceftazidime than with penicillin, chloramphenicol, or ceftriaxone. Thus, this brain cell culture model might become a supplement, complement, or even alternative technique for neurotoxicity assessment of antibiotics with proven or potential value for therapy of CNS infections. (Pediatr Res 24: 367-372, 1988)
\end{abstract}

\section{Abbreviations}

BCC, brain cell culture

CSF, cerebrospinal fluid

DIC, days in culture

CST, cerebral sulfate transferase reviews of case reports $(1,2)$. CNS toxicity is a well-described complication of intraventricular antibiotic therapy for gramnegative bacillary ventriculitis and CSF shunt infections $(1,2,4$ 7). Animal toxicity tests bear a relatively poor predictive value for neurotoxicity in man and require the use of a high number of animals $(4,5,8-10)$. Therefore, back-shifting of neurotoxicity tests from the human or animal situation to a relatively simple and reproducible system in vitro was the principal aim of the present research.

There are many reports presenting evidence of dose-dependent antiproliferative effects of various antibiotics on cultured eucaryotic cells. The cell types studied include human fibroblasts (11), bone marrow cells (12), and dissociated brain cells (13). As in vitro correlative of dose-related marrow suppression by chloramphenicol it was found several decades ago that this drug inhibits mitochondrial protein synthesis not only in bacteria but also in proliferating bone marrow cells $(14,15)$. More recently, the inhibition of cell proliferation has most often been studied for the $\beta$-lactam antibiotics on cultured human myeloid percursor and lymphoid cells, the clinical consequences being neutropenia and impairment of cellular and humoral immune responses induced by $\beta$-lactams $(12,16-18)$.

The purpose of our investigation was to monitor the effects of antibiotics on growth and differentiation in dissociated rat BCC which might help to predict human neurotoxicity. Standard and newer antibacterial agents used for meningitis and ventriculitis therapy were studied. The drug concentrations were chosen such as to represent peak values attained in ventricular CSF during intravenous therapy (19-22), and their 5 and 10 times multiples that correspond to the concentration range reached by intraventricular antibiotic administration (23-25).

Potential adverse drug effects on $\mathrm{BCC}$ were studied during the essential differentiation phase of rat CNS cells between day 10 and 17 in culture. From day 17 to 24 in culture any regeneration capacity was assumed to become manifest.

\section{MATERIALS AND METHODS}

The neurotoxicity of antibacterial agents is often overlooked or misinterpreted because of its relative infrequency and because its prediction, measurement, and monitoring is extremely difficult (1-3). The neurological side effects of antibiotics include CNS toxicity (convulsions, encephalopathy, neuropsychiatric symptoms), cranial nerve toxicity (optic neuritis, deafness, vertigo), peripheral nerve toxicity (paresthesia, motor weakness, sensory impairment), and neuromuscular blockade. Postmarketing surveillance for such adverse drug reactions has rarely been performed and clinical knowledge is almost exclusively based on

Received March 4, 1988; accepted May 24, 1988

Correspondence and requests for reprints to Urs B. Schaad, M. D., Division of Pediatric Infectious Diseases, Department of Pediatrics, University of Berne, Inselspital, CH-3010 Berne, Switzerland.

Supported in part by a grant from Glaxo Group Research Ltd., Greenford, England.
Cultures. Dissociated brain cells were prepared from newborn rats (Sprague-Dawley) as previously described (26) except that no trypsin was used. A $10-\mathrm{ml}$ aliquot of cell suspension $\left(10^{5}\right.$ cells/ml) was seeded into culture dishes that immediately before had been exposed for $1 \mathrm{~h}$ to Poly-L-Lysine (Sigma P-1524) and Eagle medium (Dulbecco) supplemented with $10 \%$ fetal calf serum. This basic culture medium contained no antibiotics and was changed on $3,6,8,10,13,15,17,20$, and $22 \mathrm{DIC}$ at $37^{\circ} \mathrm{C}$ and $5 \% \mathrm{CO}_{2}$. Each experiment was performed in triplicate. For each test culture with antibiotics added there was a control culture without antibiotics. Cell viability during culture process was regularly assessed by macroscopic and phase contrast microscopic examination. washed for $1 \mathrm{~h}$ with sterile water. The medium used was modified 
Addition of antimicrobial agents. The drugs and concentrations tested are listed in Table 1. The pure antibiotics were obtained through the hospital pharmacy and were available as either sodium salt (penicillin, cephalosporins, chloramphenicol) or sulfate (aminoglycosides) to be dissolved in sterile water. Generic names, trade names, and manufacturers of the study drugs were: benzylpenicillin sodium (penicillin G, Hoechst), streptomycin sulfate (Streptothenat, Grünenthal), amikacin sulfate (Amikin, Bristol-Myers), chloramphenicol sodium succinate (Chloromycetin, Parke-Davis), cefuroxime sodium (Zinacef, Glaxo), ceftriaxone sodium (Rocephin, Roche), and ceftazidime sodium (Fortam, Glaxo). Aliquots of concentrated stock solutions were stored at $-20^{\circ} \mathrm{C}$.

The antimicrobial agents were added to the BCC medium to get the final concentration per $\mathrm{ml}$ of medium given in Table 1 on DIC 10,13, and 15. Antibiotics were mixed with the medium by agitation of the dish. From DIC 17 on, only antibiotic-free medium was used again. Exposure to antibiotic in test BCC was therefore 7 days (DIC 10-17).

Analytical methods. At DIC 10 (days 0-10 control and test BCC without antibiotics), 14 and 17 (days 10-17 exposure to antibiotics in test BCC), and 24 (days 17-24 control and test BCC without antibiotics) the cultured cells were harvested by scraping with a rubber policeman, washed, and centrifuged. The

Table 1. Antimicrobial agents and concentrations tested

\begin{tabular}{lrrr}
\hline \multicolumn{1}{c}{ Drugs } & \multicolumn{3}{c}{$\begin{array}{c}\text { Concentrations } \\
\text { (per ml medium) }\end{array}$} \\
\hline Penicillin G (sodium) + & $200 \mathrm{IU}$ & & \\
streptomycin (sulfate) & $50 \mu \mathrm{g}$ & & \\
Penicillin G* & $20 \mathrm{IU}$ & $100 \mathrm{IU}$ & $200 \mathrm{IU}$ \\
Amikacin (sulfate) & $10 \mu \mathrm{g}$ & $50 \mu \mathrm{g}$ & $100 \mu \mathrm{g}$ \\
Chloramphenicol (sodium & $20 \mu \mathrm{g}$ & $100 \mu \mathrm{g}$ & $200 \mu \mathrm{g}$ \\
$\quad$ succinate) & & & \\
Cefuroxime (sodium) & $20 \mu \mathrm{g}$ & $100 \mu \mathrm{g}$ & $200 \mu \mathrm{g}$ \\
Ceftriaxone (sodium) & $20 \mu \mathrm{g}$ & $100 \mu \mathrm{g}$ & $200 \mu \mathrm{g}$ \\
Ceftazidime (sodium) & $20 \mu \mathrm{g}$ & $100 \mu \mathrm{g}$ & $200 \mu \mathrm{g}$ \\
\hline
\end{tabular}

* Concentrations of penicillin $\mathrm{G}$ given in $\mathrm{IU} / \mathrm{ml} ; 20 \mathrm{IU} / \mathrm{ml}=11.2 \mu \mathrm{g} /$ $\mathrm{ml}, 100 \mathrm{IU} / \mathrm{ml}=56 \mu \mathrm{g} / \mathrm{ml} ; 200 \mathrm{IU} / \mathrm{ml}=112 \mu \mathrm{g} / \mathrm{ml}$. cell sediments were kept frozen at $-20^{\circ} \mathrm{C}$ until assayed within 3 wk. Complete homogenization of brain cells was secured by thawing and addition of $200 \mu \mathrm{l}$ of homogenization buffer (50 $\mathrm{mM} \mathrm{NaH} \mathrm{PO}_{4}, 1 \mathrm{mM}$ EDTA Na 2 , Triton X-100 1\%, pH 7.0). Total protein was determined by the method of Lowry et al. (27), and total DNA according to Hinegardner (28). Activity of CST was assayed as previously described (29). Accumulation of protein and DNA reflects brain cell growth (26) whereas CST activity parallels brain cell differentiation (29).

Drugs assays. Antibiotic concentrations were measured in culture medium and brain cell lysates of some of the BCC experiments with the aim to determine half-life in medium and penetration into brain cells. The assay methods used were enzyme immunoassay technique for amikacin (30) and high-pressure liquid chromatography for cefuroxime (31), ceftriaxone (32), and ceftazidime (33). Assays of penicillin, streptomycin, and chloramphenicol were not performed.

Statistics. Significance between test and control BCC measurements of protein and DNA content and CST activity was determined using the paired Student's $t$ test on two to four separate experiments performed in triplicate. The results were confirmed by the paired Wilcoxon test (34).

\section{RESULTS}

Cell growth and differentiation. Macro- and microscopic examinations indicated regular growth of morphologically normal brain cells. To compare the sensitivity of the present rat BCC model to the previously used mouse BCC model (13), the experiment with the penicillin/streptomycin combination (200 IU/50 $\mu \mathrm{g} / \mathrm{ml}$ culture medium) generally used to maintain sterility in cell cultures was first repeated. As shown in Table 2 this drug combination compared to control reduced significantly DNA content at DIC $14(p<0.05)$ and CST activity at DIC $17(p<$ 0.001 ) as reported before (13).

The lower and intermediate drug concentrations tested (Table 1) had no effect on the different parameters studied (12 experiments in triplicate, data not shown). The results of protein concentration (mg/culture), DNA concentration ( $\mu \mathrm{g} /$ culture), and CST activity ( $\mathrm{pmol} / \mathrm{h} / \mathrm{mg}$ protein) measurements at DIC $10,14,17$, and 24 in the six experiments with the highest antibiotic concentrations studied are listed in Tables 2 and 3 as

Table 2. Effects of highest drug concentrations studied of penicillin/streptomycin, penicillin, amikacin, and chloramphenicol on dissociated $B C C$ (mean values $\pm S D$ )

\begin{tabular}{|c|c|c|c|c|c|c|c|c|c|c|c|}
\hline \multirow{2}{*}{$\begin{array}{c}\text { Antibiotics } \\
\text { (per ml medium) }\end{array}$} & \multirow[b]{2}{*}{ DIC } & \multirow[b]{2}{*}{$n^{*}$} & \multicolumn{3}{|c|}{ Protein (mg/culture) } & \multicolumn{3}{|c|}{ DNA $(\mu \mathrm{g} /$ culture $)$} & \multicolumn{3}{|c|}{$\mathrm{CST}(\mathrm{pmol} / \mathrm{h} / \mathrm{mg}$ protein $)$} \\
\hline & & & Control & Test & $p \dagger$ & Control & Test & $p \dagger$ & Control & Test & $p$ \\
\hline \multirow{4}{*}{$\begin{array}{l}\text { Penicillin }(200 \mathrm{IU})+ \\
\text { streptomycin }(50 \\
\mu \mathrm{g})\end{array}$} & 10 & 9 & $0.6 \pm 0.2$ & & & $80 \pm 18$ & & & $6.5 \pm 2.0$ & & \\
\hline & 14 & 9 & $0.8 \pm 0.1$ & $0.8 \pm 0.1$ & NS & $109 \pm 9$ & $98 \pm 10$ & $<0.05$ & $10.5 \pm 1.4$ & $10.5 \pm 1.8$ & NS \\
\hline & 17 & 9 & $1.0 \pm 0.1$ & $0.9 \pm 0.2$ & NS & $106 \pm 17$ & $104 \pm 20$ & NS & $14.1 \pm 3.9$ & $7.7 \pm 0.9$ & $<0.001$ \\
\hline & 24 & 9 & $1.3 \pm 0.1$ & $1.3 \pm 0.1$ & NS & $114 \pm 9$ & $114 \pm 21$ & NS & $14.1 \pm 1.9$ & $14.1 \pm 1.6$ & NS \\
\hline \multirow[t]{4}{*}{ Penicillin (200 IU) } & 10 & 12 & $0.6 \pm 0.1$ & & & $70 \pm 12$ & & & $9.6 \pm 0.8$ & & \\
\hline & 14 & 12 & $1.2 \pm 0.1$ & $1.2 \pm 0.1$ & NS & $131 \pm 22$ & $126 \pm 23$ & NS & $11.3 \pm 1.2$ & $11.5 \pm 0.7$ & NS \\
\hline & 17 & 12 & $1.2 \pm 0.3$ & $1.2 \pm 0.3$ & NS & $112 \pm 15$ & $113 \pm 23$ & NS & $14.0 \pm 1.1$ & $13.0 \pm 2.3$ & NS \\
\hline & 24 & 12 & $1.6 \pm 0.3$ & $1.5 \pm 0.2$ & NS & $140 \pm 27$ & $126 \pm 29$ & NS & $27.6 \pm 3.3$ & $27.5 \pm 4.1$ & NS \\
\hline \multirow[t]{4}{*}{ Amikacin $(100 \mu \mathrm{g})$} & 10 & 9 & $0.4 \pm 0.2$ & & & $39 \pm 15$ & & & $4.1 \pm 1.4$ & & \\
\hline & 14 & 9 & $0.8 \pm 0.2$ & $0.8 \pm 0.2$ & NS & $71 \pm 13$ & $69 \pm 19$ & NS & $5.1 \pm 0.7$ & $3.8 \pm 0.3$ & $<0.001$ \\
\hline & 17 & 9 & $0.9 \pm 0.2$ & $1.0 \pm 0.1$ & NS & $74 \pm 21$ & $87 \pm 34$ & NS & $7.7 \pm 0.4$ & $5.3 \pm 0.7$ & $<0.001$ \\
\hline & 24 & 9 & $1.3 \pm 0.4$ & $1.4 \pm 0.4$ & NS & $91 \pm 22$ & $91 \pm 27$ & NS & $9.5 \pm 1.5$ & $8.0 \pm 1.1$ & $<0.01$ \\
\hline \multirow{4}{*}{$\begin{array}{l}\text { Chloramphenicol } \\
(200 \mu \mathrm{g})\end{array}$} & 10 & 9 & $0.3 \pm 0.1$ & & & $27 \pm 6$ & & & $2.6 \pm 2.4$ & & \\
\hline & 14 & 9 & $1.2 \pm 0.2$ & $1.4 \pm 0.1$ & NS & $84 \pm 8$ & $89 \pm 14$ & NS & $10.1 \pm 2.5$ & $9.1 \pm 1.0$ & NS \\
\hline & 17 & 9 & $0.7 \pm 0.1$ & $0.7 \pm 0.1$ & NS & $64 \pm 18$ & $66 \pm 10$ & NS & $13.9 \pm 1.9$ & $13.6 \pm 1.5$ & NS \\
\hline & 24 & 9 & $0.9 \pm 0.2$ & $0.8 \pm 0.2$ & NS & $90 \pm 24$ & $75 \pm 17$ & NS & $14.4 \pm 3.0$ & $16.2 \pm 1.5$ & NS \\
\hline
\end{tabular}

* Number of culture plates analyzed.

$\dagger$ Student's $t$ test between test (with antibiotics) and control cultures (without antibiotics). 
mean values \pm SD. A statistically significant inhibition of cell growth (protein and DNA synthesis) or an effect on cell differentiation (CST activity) became manifest at exposure to $100 \mu \mathrm{g} /$ $\mathrm{ml}$ of amikacin, $200 \mu \mathrm{g} / \mathrm{ml}$ of cefuroxime, and $200 \mu \mathrm{g} / \mathrm{ml}$ of ceftazidime. The most pronounced differences compared to control $(p<0.001)$ were found at DIC 14 and 17, whereas at DIC 24 the majority of inhibitory effects had disappeared. In Figure 1 the changes in protein and DNA content, and CST activity during $\mathrm{BCC}$ control and test experiments with the two-third generation cephalosporins ceftriaxone and ceftazidime at concentration of $200 \mu \mathrm{g} / \mathrm{ml}$ medium are depicted. The transient decrease of CST activity at DIC 17 observed during exposure to $200 \mu \mathrm{g} / \mathrm{ml}$ of ceftazidime clearly contrasts to control and ceftriaxone experiments.

In Figures 2 and 3 the measured values of DNA content and CST activity in test cultures are expressed in percent of these values as compared to control cultures. The relative effect of the three different drug concentrations of the six antibiotics included in this study are shown at DIC 14, 17, and 24. As stated before, lower and intermediate drug concentrations did not produce any substantial reduction. The statistically significant inhibitory effects of $100 \mu \mathrm{g} / \mathrm{ml}$ of amikacin, $200 \mu \mathrm{g} / \mathrm{ml}$ of cefuroxime, and $200 \mu \mathrm{g} / \mathrm{ml}$ of ceftazidime are also evident in the percent data presentation.

Drug levels. The antibiotic concentrations measured in culture medium showed potency loss over 2 days at $37^{\circ} \mathrm{C}$ of approximately $10 \%$ for amikacin and approximately $50 \%$ for the cephalosporins.

Drug concentration measurements in cell lysate revealed for amikacin a cell penetration of approximately $50 \%$ at DIC 14 , of approximately $80 \%$ at DIC 17 , and of approximately $60 \%$ at DIC 24. Mean values found in cell lysate of experiments with the three amikacin concentrations of $10 / 50 / 100 \mu \mathrm{g} / \mathrm{ml}$ culture medium were: DIC 14, 5.2/27.2/48.7 $\mu \mathrm{g} / \mathrm{ml}$; at DIC $17,7.1 /$ $41.3 / 79.0 \mu \mathrm{g} / \mathrm{ml}$; and at DIC $24,5.8 / 30.8 / 55.3 \mu \mathrm{g} / \mathrm{ml}$. For the cephalosporins, the great majority $(>90 \%)$ of drug assays in cell lysates did not detect any measurable concentration, the lower limit of detection being $1.0 \mu \mathrm{g} / \mathrm{ml}$.

\section{DISCUSSION}

The results of the present study demonstrated reversible inhibition of CST activity and to a lesser extent of DNA synthesis in $\mathrm{BCC}$ by the highest concentrations studied of amikacin, cefuroxime, and ceftazidime. Accumulation of protein and DNA reflects brain cell growth (26) whereas CST activity parallels brain cell differentiation (29). The antibacterial agents were added to $\mathrm{BCC}$ from 10 to $17 \mathrm{DIC}$ which corresponds to the essential differentiation phase of rat CNS cells (26). Dissociated BCC consist to a major part of oligodendrocytes besides astrocytes and neurons
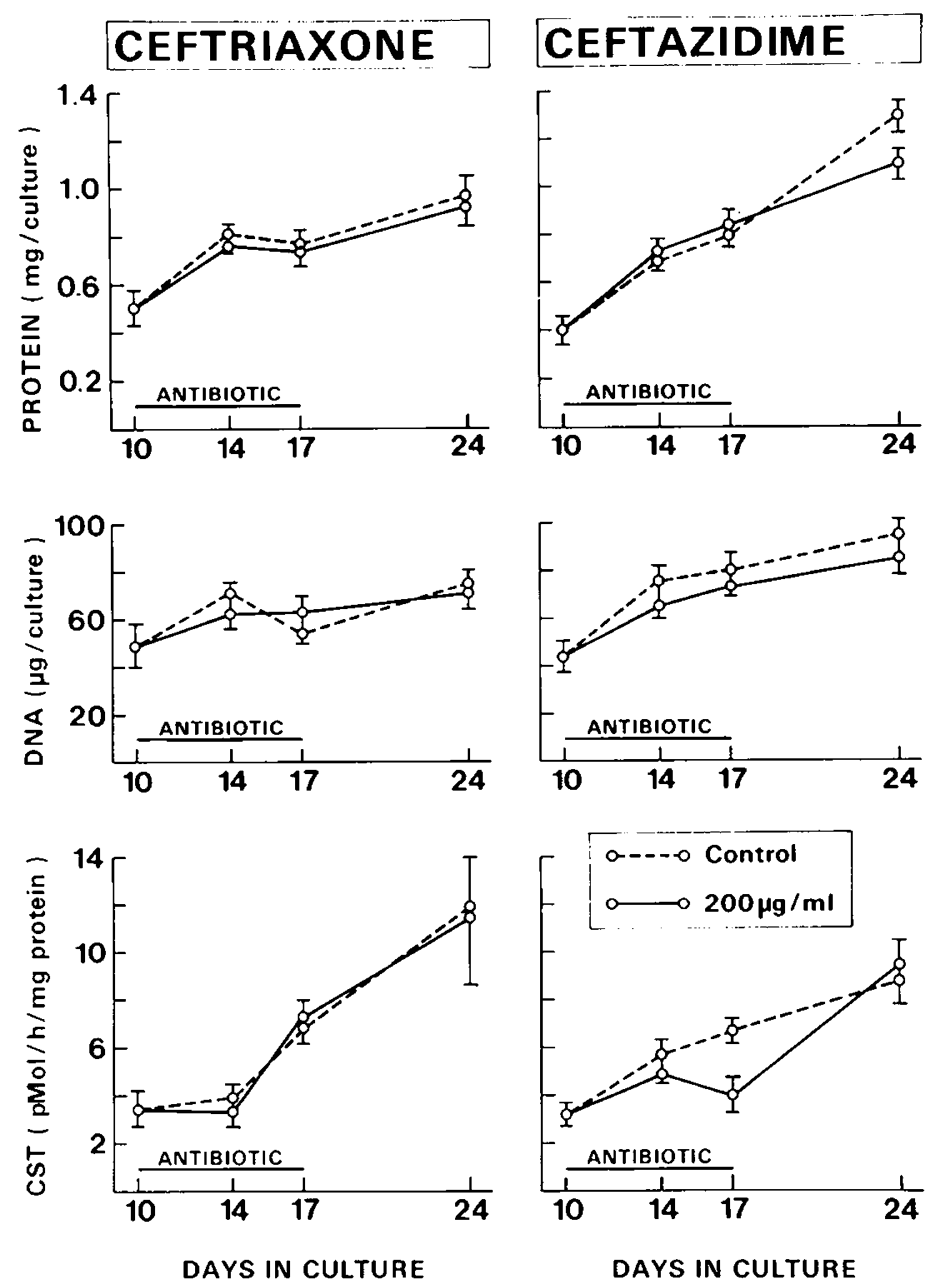

Fig. 1. Changes in total protein and DNA concentrations (per culture) and CST activity (per mg protein) during control (no antibiotics) and test BCC experiments with ceftriaxone and ceftazidime: $200 \mu \mathrm{g} / \mathrm{ml}$ of medium from day 10 to 17 . Mean values $\pm \mathrm{SEM}, n=9$.

Table 3. Effects of highest drug concentrations studied of cefuroxime, ceftriaxone, and ceftazidime on dissociated BCC (mean values $\pm S D$ )

\begin{tabular}{|c|c|c|c|c|c|c|c|c|c|c|c|}
\hline \multirow{2}{*}{$\begin{array}{c}\text { Antibiotics } \\
\text { (per ml medium) }\end{array}$} & \multirow[b]{2}{*}{$\mathrm{DIC}$} & \multirow[b]{2}{*}{$n^{*}$} & \multicolumn{3}{|c|}{ Protein (mg/culture) } & \multicolumn{3}{|c|}{ DNA $(\mu \mathrm{g} /$ culture $)$} & \multicolumn{3}{|c|}{ CST (pmol/h/mg protein) } \\
\hline & & & Control & Test & $p \dagger$ & Control & Test & $p \dagger$ & Control & Test & $p \dagger$ \\
\hline Cefuroxime & 10 & 6 & $0.4 \pm 0.1$ & & & $63 \pm 14$ & & & $7.5 \pm 2.2$ & & \\
\hline \multirow[t]{3}{*}{$(200 \mu \mathrm{g})$} & 14 & 6 & $0.9 \pm 0.2$ & $0.9 \pm 0.2$ & NS & $103 \pm 12$ & $81 \pm 19$ & $<0.01$ & $8.1 \pm 0.9$ & $6.3 \pm 0.4$ & $<0.01$ \\
\hline & 17 & 6 & $0.8 \pm 0.2$ & $0.9 \pm 0.1$ & NS & $74 \pm 40$ & $54 \pm 15$ & NS & $11.1 \pm 0.6$ & $9.3 \pm 1.3$ & NS \\
\hline & 24 & 6 & $1.2 \pm 0.1$ & $1.2 \pm 0.1$ & NS & $105 \pm 20$ & $100 \pm 17$ & NS & $16.8 \pm 3.6$ & $15.3 \pm 3.6$ & NS \\
\hline \multirow{4}{*}{$\begin{array}{l}\text { Ceftriaxone } \\
\qquad(200 \mu \mathrm{g})\end{array}$} & 10 & 9 & $0.5 \pm 0.2$ & & & $49 \pm 18$ & & & $3.4 \pm 2.2$ & & \\
\hline & 14 & 9 & $0.8 \pm 0.1$ & $0.8 \pm 0.1$ & NS & $70 \pm 7$ & $63 \pm 13$ & NS & $3.9 \pm 1.0$ & $3.3 \pm 1.9$ & NS \\
\hline & 17 & 9 & $0.8 \pm 0.1$ & $0.8 \pm 0.2$ & NS & $54 \pm 11$ & $63 \pm 20$ & NS & $6.9 \pm 2.2$ & $7.2 \pm 2.4$ & NS \\
\hline & 24 & 9 & $1.0 \pm 0.3$ & $0.9 \pm 0.3$ & NS & $74 \pm 16$ & $73 \pm 22$ & NS & $11.9 \pm 6.2$ & $11.6 \pm 9.1$ & NS \\
\hline \multirow{4}{*}{$\begin{array}{l}\text { Ceftazidime } \\
\quad(200 \mu \mathrm{g})\end{array}$} & 10 & 9 & $0.4 \pm 0.1$ & & & $44 \pm 19$ & & & $3.2 \pm 0.7$ & & \\
\hline & 14 & 9 & $0.7 \pm 0.1$ & $0.7 \pm 0.1$ & NS & $75 \pm 23$ & $65 \pm 15$ & NS & $5.7 \pm 1.6$ & $4.9 \pm 0.8$ & NS \\
\hline & 17 & 9 & $0.8 \pm 0.1$ & $0.8 \pm 0.2$ & NS & $80 \pm 11$ & $74 \pm 11$ & NS & $6.7 \pm 1.1$ & $4.0 \pm 0.9$ & $<0.001$ \\
\hline & 24 & 9 & $1.3 \pm 0.2$ & $1.1 \pm 0.2$ & NS & $94 \pm 20$ & $85 \pm 22$ & NS & $8.8 \pm 2.7$ & $9.4 \pm 2.8$ & NS \\
\hline
\end{tabular}

* Number of culture plates analyzed.

† Student's $t$ test between test (with antibiotics) and control cultures (without antibiotics). 
DNA PENICILLIN $\square 20$ IU VU1001U 200 IU
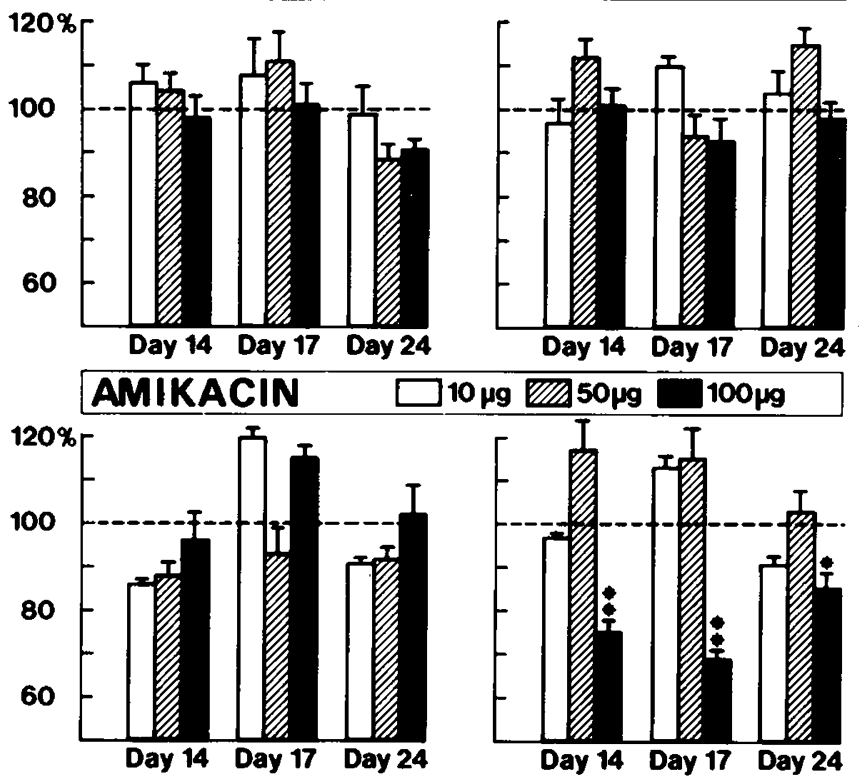

CHLORAMPHENICOL
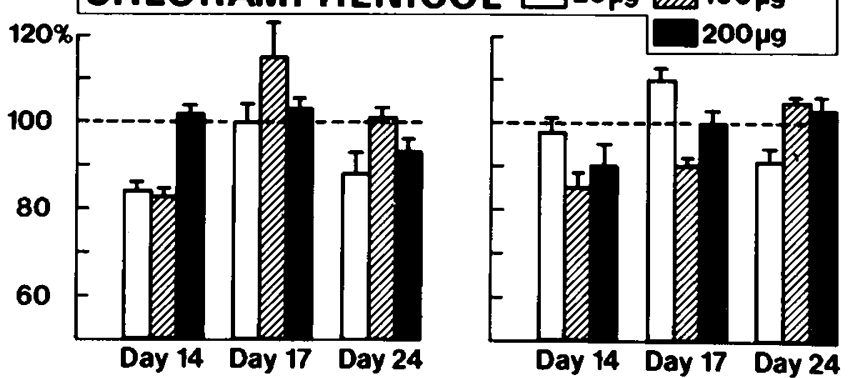

DNA CST
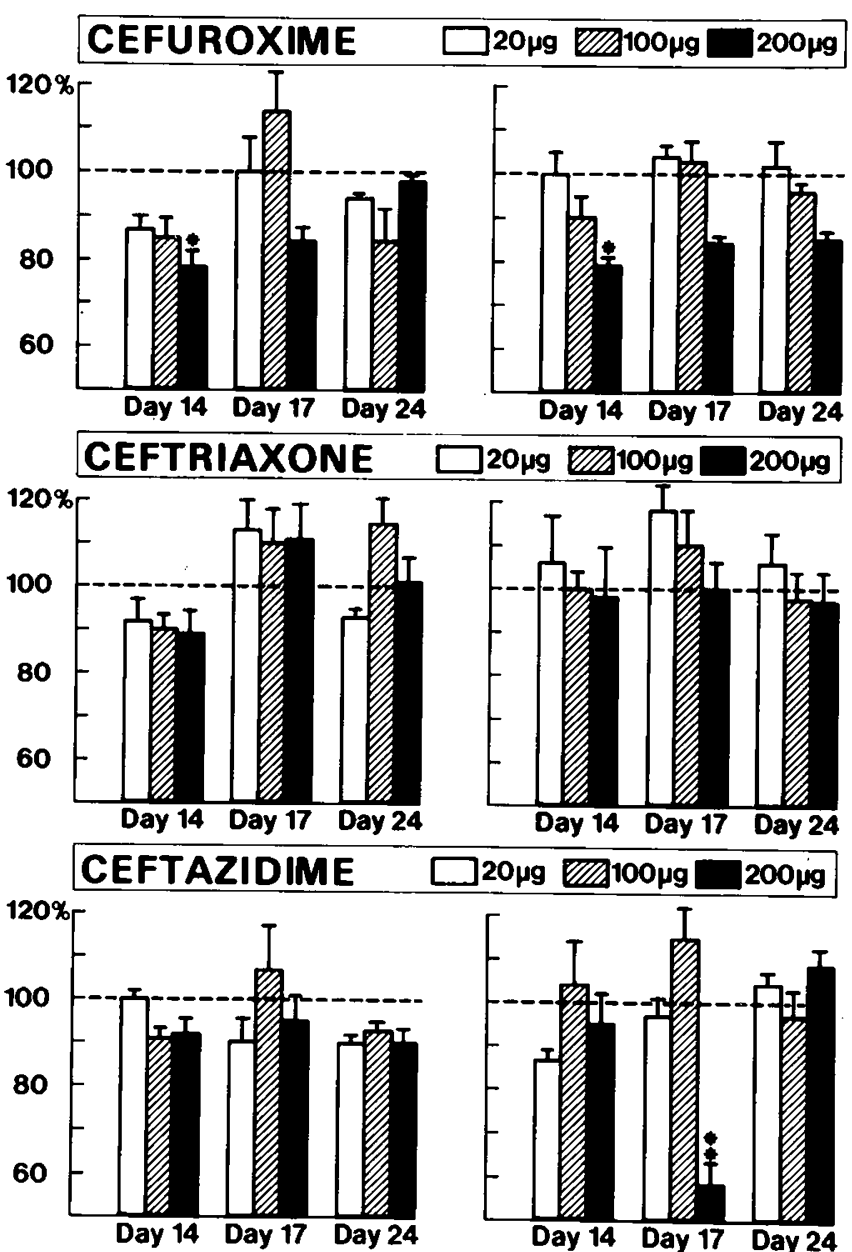

Figs. 2 and 3. Effects of three different drug concentrations (per ml of medium) of the six study antibiotics on DNA content and CST activity in BCC. Mean values of six to nine experiments with antibiotics added from day 10 to 17 are expressed in percent of corresponding control cultures without any antibiotics. Vertical bars represent SEM; ${ }^{*} p<0.01 ;{ }^{* *} p<0.001$.

(35). Our data suggest that certain antibiotics exhibit a dosedependent suppressive effect on differentiation and to a lesser extent on proliferation of oligodendrocytes in rat BCC. Both of these drug actions showed complete regeneration during the antibiotic-free period from 17 to 24 DIC and did not affect cell viability. These experimental data could indicate that the drugs principally interact with enzyme activity. This interpretation of drug mechanism is consistent with recent publications demonstrating dose-dependent inhibition of the replicative DNA polymerase enzyme in eucaryotic cells by $\beta$-lactam antibiotics (17, 18). Interestingly, the same research group has established a rank order of $\beta$-lactams for their inhibitory capacity on bone marrow cultures $(12,18)$ with good correlation to clinical induction of neutropenia. The suppressive effects of the $\beta$-lactams studied in our BCC model followed the same rank order: ceftazidme $>$ cefuroxime $>$ ceftriaxone and penicillin. It is possible that the negative drug effects on cell proliferation and differentiation are more pronounced in cultured cell populations more rapidly dividing than rat $\mathrm{BCC}$.

The inhibitory potency of $\beta$-lactams on in vitro granulopoiesis seems to be substantially enhanced by drug degradation (16). However, the convulsant effect, like the antimicrobial effect, depends on the presence of the intact $\beta$-lactam ring $(2,36)$. It has been shown in animal experiments that penicillinase-treated penicillin $\mathrm{G}$ is no more epileptogenic (37).
The most pronounced effect in our experiments was the inhibition of CST activity by amikacin in the concentration of 100 $\mu \mathrm{g} / \mathrm{ml}$ medium. The primary mode of bactericidal action of aminoglycosides is due to their specific attachment to ribosomes and subsequent disruption of the translation mechanism of the cell $(38,39)$. It has been speculated that these mechanisms also account for the use of aminoglycosides as inhibitors of eucaryotic cells in the development of interspecific cloning vectors (39). Reduced CST activity could reflect impaired CST synthesis due to ribosomal interaction of amikacin in the BCC model.

Antibiotic concentration measurements in culture medium confirmed the anticipated potency loss within 2 days of approximately $10 \%$ for amikacin and approximately $50 \%$ for the cephalosporin compounds. Attempts to assess drug cell penetration in this in vitro model were based on antibiotic determination in cell lysates (40). The assumed high cell penetration of amikacin was confirmed whereas the cephalosporin data proved to be too variable to allow any conclusion concerning brain cell-associated antibiotic. Penetration of antibiotics into eucaryotic cells is extremely complex and depends on a variety of factors such as lipid solubility, protein binding, molecular size, and structure of both, cell membrane and intracellular organelles $(40,41)$. In addition to limited brain cell penetration also binding to cellular structures and potency loss could have been responsible for the in $>90 \%$ nondetectable cephalosporin concentrations in the cell 
lysates. A possible relation between cell penetration and suppressive effects of antibiotics in this BCC model is not assessable by our data.

The limited clinical knowledge on neurotoxicity of antimicrobial agents (1-3) and difficulties in extrapolating in vivo animal models $(4,5,8-10)$ prompted the present in vitro research. The advantages of in vitro assessment are better reproducibility and smaller number of variables. Prognosis of gram-negative bacillary ventriculitis and CSF shunt infections remains relatively poor. The major therapeutic problems of these CNS infections are antibiotic resistance of involved, often nosocomially acquired, gram-negative and gram-positive pathogens, and limited drug penetration into CSF because of narrow therapeutic drug index or only low-grade meningeal inflammation $(6,7)$. Therefore, to produce larger antibiotic concentrations in CSF direct drug inoculation is often recommended in addition to systemic therapy $(6,7,23,24,42)$. Neurotoxicity represents a potential hazard for intraventricular antibiotic administration and has been clinically and experimentally repeatedly observed $(1,2,4,23-25)$. Histopathologic changes in rabbits due to gentamicin included ependymal and brain cell damages $(4,5)$. The highest antibiotic concentrations studied in our experiments correspond to the peak values in CSF attained by intraventricular administration in patients $(6,7,23,24,42)$. To imitate the clinical situation of intraventricular therapy the study drugs were taken from regular injectable drug vials as sodium or sulfate salts. Therefore, our experiments do not allow to exclude effects of the salt components on BCC.

We conclude that the in vitro phenomena observed in these studies could have some predictive value for clinical neurotoxicity. The no-effect levels may be of at least equal significance as the toxic-effect levels. Simple extrapolation of results of toxic effects from in vitro to in vivo situation and across species is obviously unrealistic (9). The major limitations of our in vitro test system for drug neurotoxicity are elimination of blood-brain barrier, lack of metabolic and elimination functions, and absence of inflammation. We suggest that the clinical use of antimicrobial agents that produce significant inhibition of cell growth and differentiation in this BCC model implies close monitoring for potential neurotoxicity, especially during intraventricular drug administration.

Inclusion of histopathologic and immunofluorescent studies (35), analysis for degradation products of antibiotics $(16,18)$, and evaluation of the salt component of antibiotic might add to the predictive value of our model. These studies are part of our planned further investigations.

Implications. Our findings indicate that intraventricular therapy could produce more neurotoxicity with amikacin, cefuroxime, and ceftazidime than with penicillin, chloramphenicol, or ceftriaxone. So far, clinical experience with intraventricular amikacin, cefuroxime, ceftazidime, and also ceftriaxone administration is very scant and, to our knowledge, neurologic side effects have not been reported. Careful monitoring for neurotoxic signs and symptoms is mandatory in such patients. We suggest that the sensible use of our BCC model could represent an important component in the early assessment for neurotoxicity of antimicrobial agents with proven or potential value for therapy of CNS infections.

Acknowledgments. The authors thank Dr. C. Bachmann for critical comments on the manuscript, Dr. Th. Zysset, A. M. Harris, and Dr. K. Stoeckel for technical assistance, and F. Bacher for secretarial services.

\section{REFERENCES}

1. Snavely SR, Hodges GR 1984 The neurotoxicity of antibacterial agents. Ann Intern Med 101:92-104

2. Ricci S, Del Favero A, Longo VG 1986 Central nervous system side-effects of anti-infectious drugs. Drugs Today 22:283-300

3. Neu HC 1986 Assessments of potential toxic effects of antimicrobial agents in man. In: O'Grady FW, Perciavl A (eds) Prediction and Assessment of Antibiotic Clinical Efficacy. Academic Press, London, pp 119-140

4. Watanabe I, Hodges GR, Dworzack DL, Kepes JJ, Duensing GF 1978 Neurotoxicity of intrathecal gentamicin: a case report and experimental study. Ann Neurol 4:564-572

5. Hodges GR, Watanabe I, Singer P, Rengachary S, Reeves D, Jusetesen DR Worley SE, Gephardt EP 1981 Central nervous system toxicity of intraventricularly administered gentamicin in adult rabbits. J Infect Dis 143:148155

6. Swartz NM 1981 Intraventricular use of aminoglycosides in the treatment of gram-negative bacillary meningitis: conflicting views. J Infect Dis 143:293296

7. Wald SL, McLaurin RL 1980 Cerebrospinal fluid antibiotic levels during treatment of shunt infections. J Neurosurg 52:41-46

8. Weiss MH, Kurze T, Nulsen FE 1974 Antibiotic neurotoxicity-laboratory and clinical study. J Neurosurg 41:486-489

9. Worden AN 1986 Animal toxicity test and possible alternatives. In: O'Grady FW, Percival A (eds) Prediction and Assessment of Antibiotic Clinical Efficacy. Academic Press, London, pp 103-117

10. Flack JD 1986 Toxicity: ritual, rationale and regulatory requirements. In O'Grady FW, Percival A (eds) Prediction and Assessment of Antibiotic Clinical Efficacy. Academic Press, London, pp 141-157

11. Goetz IE, Moklebust R, Warren CJ 1979 Effects of some antibiotics on the growth of human diploid skin fibroblasts in cell culture. In Vitro 15:114 119

12. Neftel KA, Hauser SP, Müller MR 1985 Inhibition of granulopoiesis in vivo and in vitro by beta-lactam antibiotics. J Infect Dis 152:90-98

13. Amonn F, Baumann U, Wiesmann UN, Hofmann K, Herschkowitz N 1978 Effects of antibiotics on the growth and differentiation in dissociated brain cell cultures. Neuroscience 3:465-468

14. Yunis AA, Harrington WJ 1960 Patterns of inhibition of chloramphenicol of nucleic acid synthesis in human bone marrow and leukemic cells. J Lab Clin Med 56:831-838

15. Laferriere CI, Marks MI 1982 Chloramphenicol: properties and clinical use. Pediatr Infect Dis 1:257-264

16. Neftel KA, Müller MR, Wälti M, Erni J, Gugler M, Arrenbrecht S 1983 Penicillin-G degradation products inhibit in vitro granulopoiesis. $\mathrm{Br} \mathrm{J} \mathrm{Hae}-$ matol 54:255-260

17. Hübscher U, Huynh UD, Hässig M, Neftel KA 1986 Effects of beta-lactams on DNA replication. Cell Biol Toxicol 2:541-548

18. Neftel KA, Hübscher U 1987 Effects of beta-lactam antibiotics on proliferating eucaryotic cells. Antimicrob Agents Chemother 31:1657-1661

19. Barling RWA, Selkon JB 1978 The penetration of antibiotics into cerebrospinal fluid and brain tissue. J Antimicrob Chemother 4:203-227

20. Richards ML, Prince RA, Kenaley KA, Johnson JA, LeFrock JL 1981 Antimicrobial penetration into cerebrospinal fluid. Drug Intell Clin Pharm 15:341-368

21. Jogew R, Kolling WM 1981 Intraventricular levels of amikacin after intravenous administration. Antimicrob Agents Chemother 20:583-586

22. Schaad UB 1984 The cephalosporin compounds in severe neonatal infection. Eur J Pediatr 141:143-146

23. McCracken GH Jr, Mize SG, Threlkeld N 1980 Intraventricular gentamicin therapy in gram-negative bacillary meningitis of infancy. Report of the second neonatal meningitis cooperative study group. Lancet 1:787-791

24. Wright PF, Kaiser AB, Bowman CM, McKee $\mathrm{KT}$ Jr, Trujillo $\mathrm{H}$, McGee ZA 1981 The pharmacokinetics and efficacy of an aminoglycoside administered into the cerebral ventricles in neonates: implications for further evaluation of this route of therapy in meningitis. J Infect Dis 143:141-147

25. Schaad UB, McCracken GH Jr 1981 Pharmacologic basis for antimicrobial therapy of neonatal meningitis. Helv Paediat Acta 36:19-30

26. Wiesmann UN, Hofmann K, Burkart T, Herschkowitz N 1975 Dissociated cultures of newborn mouse brain. I. Metabolism of sulfatid lipids and mucopolysaccharides. Neurobiology 5:305-315

27. Lowry OH, Rosebrough NJ, Farr AL, Randall RJ 1951 Protein measurement with the folin phenol reagent. J Biol Chem 193:265-275

28. Hinegardner RT 1971 An improved fluorometric assay for DNA. Anal Biochem 39:197-20

29. Siegrist HP, Burhart T, Steck AJ, Wiesmann U, Herschkowitz N 1976 Influence of lipids on the activity of cerebrosid-sulphotransferase in mouse brain: a comparative study of Jimpy and normal mouse brain. J Neurochem 27:599604

30. Fukuchi H, Yoshida M, Tsukiai S, Kitaura T, Konishi T 1984 Comparison of enzyme immunoassay, radioimmunoassay, and microbiologic assay for amikacin in plasma. Am J Hosp Pharm 41:690-693

31. Harding SM, Williams PEO, Ayrton J 1984 Pharmacology of cefuroxime as the l-acetoxyethyl ester in volunteers. Antimicorb Agents Chemother 25:78 82

32. Trautmann KH, Haefelfinger P 1981 Determination of Ro 13-9904 in plasma urine and bile by means of ion-pair reversed phase chromatography. J High Resol Chromatogr Commun 4:54-59

33. Ayrton J 1981 Assay of ceftazidime in biological fluids using high-pressure liquid chromatography. J Antimicrob Chemother 8(suppl B):227-331

34. Brown BW Jr 1971 Statistics: A Biomedical Introduction. J Wiley \& Sons, New York

35. Bologa-Sandru L, Siegrist HP, Z'Graggen A, Hofmann K, Wiesmann U, Dah 
D, Herschkowitz N 1981 Expression of antigenic markers during the development of oligodendrocytes in mouse brain cell cultures. Brain Res 210:217229

36. Gloor P 1969 Epileptogenic action of penicillin. Ann NY Acad Sci 166:350360

37. Elger CE, Speckman E-J 1987 Mechanisms controlling the spatial extent of epileptic foci. In: Wieser HG, Speckmann E-J, Engel J Jr (eds) The Epileptic Focus. John Libbey, London, pp 45-58

38. Moellering RC Jr 1983 In vitro antibacterial activity of the aminoglycoside antibiotics. Rev Infect Dis 5:S212-S231

39. Davies J 1986 Life among the aminoglycosides. ASM News 52:620-624

40. Brown KN, Percival A 1978 Penetration of antimicrobials into tissue culture cells and leukocytes. Scand J Infect Dis 14(suppl):251-260

41. Kornguth ML, Kunin CM 1976 Uptake of antibiotics by human erythrocytes. $J$ Infect Dis 133:175-184

42. James HE, Wilson HD, Connor JD, Walsh JW 1982 Intraventricular cerebrospinal fluid antibiotic concentrations in patients with intraventricular infections. Neurosurgery 10:50-54 